\title{
The side effect of some pesticide alternatives on the population densities of the natural enemies of two piercing-sucking insect pests at the new valley province, Egypt
}

\author{
Gameel S. M. M.
}

Plant Protection Research Institute, Agricultural Research Center, Dokki, Giza

\begin{abstract}
The experimental data indicated that, regardless the effect the planted crop, Baicao2 (Matrine) and Neemix (Azadirachtin) were more toxic alternative pesticides against (Coccinella undecimpunctata aegyptiaca Reihe and Coccinella septempunctata L.). The average reduction percentages were 99.17 and $94.06 \%$ and 100.00 and $96.38 \%$ with general mean (99.58 and 95.72\%) during the two planting seasons, respectively.

The results indicate that, Biosect (Beauveria bassiana) compound was the most harmful alternative pesticide against the true spiders. This compound induced (70.19 and $72.94 \%)$ as an average reduction percentage during the early summer and Nili plantation, respectively. The lower toxic effect was obtained with the treatment by Prev (orange oil) where, the general mean reduction percentage after two seasons of application was $14.63 \%$. Baicao and Neemix showed a moderate toxic effect on the population density of the true spiders.
\end{abstract}

Keywords: pesticides- piercing-sucking pests - New Valley -Egypt

\section{INTRODUCTION}

Conventional pesticides provide many benefits to food production and nutrition, but they also pose some hazards. Some synthetic pesticides may leave undesirable residues in food, water and the environment when not used properly. Low doses of many pesticides are toxic to humans and other animals. However extensive use of pesticides in agricultural had be to the development of genetically resistant pests that are no longer affected by some commonly used pesticides (Gameel 2004). As known, in 1995 for environmental and toxicity reasons, Ministry of Agriculture in Egypt banned all conventional insecticides in the New Valley and many bioinsecticides and natural products were recorded to control the crop pests (Reed and Reed, 1986; Balazy, 1993; Yousri, et al., 1995; Abd-Rabou and Mangoud 2002 ).As a result, researchers under the New Valley conditions are seeking less hazardous alternative to control the pests of the main crops such as date palm (Gameel and Sayed 2009) and vegetables (Gameel and Sayed 2012). Vegetable plants are subjected to be attacked by several major insect pests which cause severe damage directly or indirectly to the crop production (Metwally et al., 1995 and Ghallab et al., 2011). The tomato whitefly, Bemisia tabaci (Gennadius) (Hom.- Aleyrodidae) and cotton aphid, Aphis gossypii Glover; (Hom.Aphididae) were recorded as a key piercing- sucking pests on cucurbit crops under the New Valley conditions (Gameel 2004 and Gameel and Sayed 2008). The main predator associated with these pests are (Coccinella undecimpunctata aegyptiaca Reihe and Coccinella septempunctata L.) and the true spiders (El-Maghraby et al.1994 and Younes et al. 2010).

Under the New Valley conditions, there are no literatures about the side effect of the pesticide alternatives on the population densities of the natural 
enemies these pests. Therefore, the investigation was carried out during two seasons of 2011 to evaluate the side effect of some pesticide alternatives on the population densities of the natural enemies of two homopterous pests; $B$. tabaci and A. gossypii.

\section{MATERIALS AND METHODS}

Trials were conducted in, Kharga Oasis during (early summer and summer) and Nili plantation of 2011 on cucumber and tomato plants. In the case of $A$. gossypii (nymphs \& adults), the pesticide alternative treatment was: Baicao2, 0.1 EC (Matrine) at $200 \mathrm{ml} / 100 \mathrm{~L}$. Meanwhile, the compounds 1- Neemix 4.5EC (Azadirachtin) at $75 \mathrm{ml} /$ 100 L.; 2- Prev 0.6\% EC; LimoneneR-U-Iso propyl 1-Methyl cyclohexane (orange oil) $500 \mathrm{ml} / 100 \mathrm{~L}$. and 3- Biosect WP (Beauveria bassiana (Balsamo)) 200gm / 100L.were applied against B. tabaci (nymphs \& adults).

The experimental plots were laid out in a randomized complete block design and each planting date was represented by four plots (every one equal 42 meter square).

The cucumber cultivar (F1-hybrid Beit alpha) planted during two plantations, the first in the end of March (summer plantation) and the second during the end of August (Nili plantation). While, the tomato cultivar (Super Strain B) planted during two plantations, the first in the middle of February (early summer plantation) and the second during the end of August (Nili plantation).

The nymph and adult stages of cotton aphid and the whitefly pests were counted directly on 25 leaves / replicate in the field and laboratory. The predators counted per five plants / replicate. The number of individuals was counted early at the morning before and after 2 days, 5days, 8days, 11days and two weeks in the case of $A$. gossypii and before and after one day, 3days, 5days, 8days, 11days and two weeks of treatment in the case of $B$. tabaci in controlled and uncontrolled plots. The reduction percentage was determined according to Henderson and Tilton formula (1955):

Reduction

$$
\left[\begin{array}{c}
\text { percentage } \\
1-\frac{C_{b}}{C{ }_{a}}
\end{array} \frac{T_{a}}{T_{b}}\right]
$$

where,

$\mathrm{C}_{\mathrm{b}}=$ The pre treatment mean in the untreated plots.

$\mathrm{C}_{\mathrm{a}}=$ The post treatment mean in the untreated plots.

$\mathrm{T}_{\mathrm{b}}=$ The pre treatment mean in the treated plots.

$\mathrm{T}_{\mathrm{a}}=$ The post treatment mean in the treated plots.

\section{RESULTS AND DISCUSSION}

Effect of two pesticide alternatives on the population densities of the natural enemies of two piercing-sucking insect pests infesting cucumber plants

Data in Tables 1 and 2 represented the effect of two alternative pesticides (Baicao and Neemix) against the natural enemies of $A$. gossypii and $B$. tabaci on cucumber plants during summer and Nili seasons of 2011, respectively.

Table 1: Percent reduction in the population densities of the natural enemies of A. gossypii infesting cucumber plants following treatment with Baicao pesticide alternative during summer and Nili plantations, New Valley 2011.

\begin{tabular}{|c|c|c|c|c|c|c|c|}
\hline \multirow{2}{*}{ Season } & \multirow{2}{*}{$\begin{array}{l}\text { Arthropod } \\
\text { species }\end{array}$} & \multicolumn{5}{|c|}{ Reduction (\%) } & \multirow{2}{*}{ Mean } \\
\hline & & 2days & 5days & 8days & 11days & 2weeks & \\
\hline \multirow{3}{*}{ 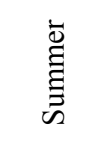 } & A. gossypii & 86.99 & 95.60 & 99.15 & 96.66 & 96.28 & 94.93 \\
\hline & $\begin{array}{c}\text { Coccinellid } \\
\text { predators }\end{array}$ & 98.02 & 97.86 & 100.00 & 10.00 & 100.00 & 99.17 \\
\hline & True spiders & 0.00 & 66.66 & 50.00 & 30.30 & 31.42 & 35.67 \\
\hline \multirow{3}{*}{$\overline{\bar{Z}}$} & A. gossypii & 90.07 & 95.65 & 99.76 & 98.13 & 97.13 & 96.14 \\
\hline & $\begin{array}{c}\text { Coccinellid } \\
\text { predators }\end{array}$ & 100.00 & 100.00 & 100.00 & 100.00 & 100.00 & 100.00 \\
\hline & True spiders & 0.00 & 60.00 & 44.44 & 25.00 & 16.67 & 29.22 \\
\hline
\end{tabular}


During summer season, data in Table 1 indicated that, Baicao alternative pesticide gave $86.99 \%$ reduction in the population size of $A$. gossypi after 2 days of application as an initial kill. This compound induced the high effect 99.15 $\%$ after 8 days of treatment with residual effect 96.28 after two weeks of application. Concerning to coccinellid predators (Coccinella undecimpunctata aegyptiaca Reihe and Coccinella septempunctata L.), this compound induced $98.02 \%$ as an initial effect after 2 days of application. The maximum effect $100.00 \%$ was recorded after 8 days of treatment and extended to 14 days in the same level of reduction percentage. In case of true spiders, Baicao induced an initial effect of $(0.00 \%)$ after 2 days of application. The maximum reduction percentage $66.66 \%$ was obtained after 5 days of treatment. A residual effect of $31.42 \%$ was recorded after 14 days of application.

During Nili plantation, the data show nearly the same trend as that of the summer plantation. The initial effect in case of cotton aphid was $90.07 \%$ and the residual reduction percentage after two weeks was $97.13 \%$. Strongly toxic effect was observed against the coccinelled beetles where, the reduction percentage of recorded $100.00 \%$ from 2 until 14 days of treatment. Relatively low effect was obtained in the case of the true spiders. The maximum effect with Baicao compound recorded after 5 days of treatment $(60.00 \%)$. The residual effect $16.67 \%$ was obtained after 16 days of application.

Data in Table 2 represented the effect of Neemix (Azadirachtin) alternative pesticide against the adult and nymph stages of $B$. tabaci and its natural enemies inhibiting cucumber plants during summer and Nili plantations. The tested compound was more affected against the adult stage of the whitefly than the nymph stage during summer season. The initial kills were $(93.10$ and $73.80 \%$ ), respectively. The high effects (93.10 and $75.63 \%$ ) against the adult and nymph stages were recorded after one day and 11days of application, respectively. On the other hand, the predators of the coccinellid beetles were more susceptible to Neemix treatment more than the true spiders where the initial toxic effects were 96.33 and $0.00 \%$ after one day of treatment, respectively.

Table 2: Percent reduction in the population densities of the natural enemies of $\mathrm{B}$. tabaci infesting cucumber plants following treatment with Neemix pesticide alternative during summer and Nili plantations, New Valley 2011.

\begin{tabular}{|c|c|c|c|c|c|c|c|c|}
\hline \multirow{2}{*}{ Season } & \multirow{2}{*}{$\begin{array}{l}\text { Arthropod } \\
\text { species }\end{array}$} & \multicolumn{6}{|c|}{ Reduction (\%) } & \multirow{2}{*}{ Mean } \\
\hline & & 1days & 3days & 5days & 8days & 11days & 2weeks & \\
\hline \multirow{4}{*}{ 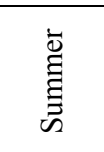 } & B. tabaci adults & 93.10 & 87.19 & 84.52 & 89.70 & 86.65 & 84.99 & 87.69 \\
\hline & B. tabaci nymphs & 73.80 & 67.22 & 49.61 & 64.74 & 75.63 & 62.12 & 65.52 \\
\hline & Coccinellid predators & 96.33 & 89.50 & 95.50 & 89.06 & 100.00 & 100.00 & 95.06 \\
\hline & True spiders & 0.00 & 20.00 & 50.76 & 68.37 & 75.75 & 73.33 & 48.03 \\
\hline \multirow{4}{*}{$\overline{\bar{z}}$} & B. tabaci adults & 91.42 & 84.00 & 80.00 & 84.00 & 83.44 & 81.53 & 84.06 \\
\hline & B. tabaci nymphs & 68.58 & 40.00 & 19.88 & 55.49 & 64.39 & 50.86 & 49.86 \\
\hline & Coccinellid predators & 100.00 & 85.00 & 93.33 & 100.00 & 100.00 & 100.00 & 96.38 \\
\hline & True spiders & 0.00 & 0.00 & 37.50 & 58.33 & 66.66 & 72.22 & 39.11 \\
\hline
\end{tabular}

The residual effects after two weeks of applications were $(73.33$ and $100.00 \%$ ), respectively. According to the treatment with Neemix during Nili season, it is clear that, the maximum reduction percentages $(91.42$ and
$68.58 \%$ ) were recorded after one day of application against the adults and nymphs of the tomato whitefly, respectively. It's clear from these results that, Neemix caused a high reduction in the coccinellid predator population which 
ranged between $85.00 \%$ and $100.00 \%$. Low initial effect $(0.00 \%)$ was obtained after one day of application with Neemix in the case of the true spiders. Meanwhile, the residual effect was $72.22 \%$ after 14 days of treatment.

1. Effect of two pesticide alternatives on the population densities of the natural enemies of $B$. tabaci infesting tomato plants
The results in Table 3 indicate the effect of Prev and Biosect against the adult stage of the B. tabaci and the true spiders inhibiting tomato plants during two seasons. In the case of B. tabaci, the initial effects were 54.54 and $81.81 \%$, and the reduction percentages after 14 days were 57.38 and $39.39 \%$ respectively for Prev and Biosect during early summer season, respectively.

Table 3: Percent reduction in the population densities of the natural enemies of $B$. tabaci infesting tomato plants following treatment with two pesticide alternatives during early summer and Nili plantations, New Valley 2011.

\begin{tabular}{|c|c|c|c|c|c|c|c|c|c|}
\hline \multirow{2}{*}{ Season } & \multirow{2}{*}{$\begin{array}{c}\text { Arthropod } \\
\text { species }\end{array}$} & \multirow{2}{*}{ Treatments } & \multicolumn{6}{|c|}{ Reduction (\%) } & \multirow{2}{*}{ Mean } \\
\hline & & & 1days & 3days & 5 days & 8 days & 11days & 2 weeks & \\
\hline \multirow{4}{*}{$\begin{array}{c}\text { Early } \\
\text { summer }\end{array}$} & B. tabaci & Prev & 54.54 & 60.93 & 53.45 & 57.03 & 47.03 & 57.38 & 55.06 \\
\hline & B. tabaci & Biosect & 81.81 & 70.98 & 60.10 & 62.50 & 37.50 & 39.39 & 58.71 \\
\hline & True spiders & Prev & 50.00 & 43.75 & 0.00 & 0.00 & 0.00 & 0.00 & 15.62 \\
\hline & True spiders & Biosect & 77.77 & 83.33 & 100.00 & 100.00 & 37.25 & 22.80 & 70.19 \\
\hline \multirow{4}{*}{ Nili } & B. tabaci & Prev & 10.00 & 20.00 & 30.43 & 27.77 & 10.34 & 13.33 & 18.64 \\
\hline & B. tabaci & Biosect & 65.71 & 42.85 & 25.46 & 38.09 & 17.24 & 14.28 & 33.93 \\
\hline & True spiders & Prev & 37.50 & 44.44 & 0.00 & 0.00 & 0.00 & 0.00 & 13.65 \\
\hline & True spiders & Biosect & 76.56 & 93.05 & 100.00 & 100.00 & 37.50 & 30.55 & 72.94 \\
\hline
\end{tabular}

Biosect induced high initial kill (77.775) against the true spiders more than Prev which recorded (50.00\%) after one day of application. The residual effects were 0.00 and $22.80 \%$ for Prev and Biosect, respectively. In Nili plantation, the data show nearly the same trend as that of the early summer plantation. Prev recorded the maximum reduction in the population of B.tabaci 30.435 after 5 days of application. Biosect caused the highest reduction (65.71\%) in the B. tabaci population after one day of treatment, then the reduction percentage declined by the time elapse to reach $(14.28 \%)$ after 21 days of application. Concerning to the side effects of the tested materials against the true spiders, Biosect was more toxic alternative pesticide against the true spiders than Prev compound. The reduction percentage ranged between $(0.00$ and $44.11 \%)$ in the case of Prev. Meanwhile, the results ranged between 30.55 and $100.00 \%$ in the case of Biosect compound.

Regardless the effect the planted crop, data in Table 4 show the average reduction percentages in the population of predators due to the treatment with tested compound during the two seasons. Baicao and Neemix were more toxic alternative pesticides against $C$. undecimpunetata and $C$. septempunetata. The average reduction percentages were 99.17 and $94.06 \%$ and 100.00 and $96.38 \%$ with general mean $(99.58$ and $95.72 \%$ ) during two planting seasons, respectively.

The results indicate that, Biosect compound was the most harmful alternative pesticide against the true spiders. This compound induced (70.19 and $72.94 \%$ ) as an average reduction percentage during the early summer and Nili plantation, respectively. The lower toxic effect was obtained by the treatment of Prev. The general mean reduction percentage after two seasons of application was $14.63 \%$. Baicao and Neemix showed a moderate toxic effect on the population density of the true spiders.

The present results indicate that, Baicao2,0.1 EC (Matrine) and Neemix 4.5EC (Azadirachtin) followed by 
Biosect WP (Beauveria bassiana) were the most effective compounds against the
B. tabaci and A. Gossypii on cucumber or tomato plants.

Table 4: Average percent reduction in the population densities of the natural enemies following treatment with some pesticide alternatives during early summer and Nili plantations, New Valley 2011.

\begin{tabular}{|c|c|c|c|c|c|}
\hline \multirow{2}{*}{ Season } & \multirow{2}{*}{$\begin{array}{c}\text { Arthropod } \\
\text { species }\end{array}$} & \multicolumn{4}{|c|}{ Average percent reduction } \\
\hline & & Neemix & Prev & Biosect & Baicao \\
\hline \multirow[t]{2}{*}{$\begin{array}{c}\text { Early summer } \\
\text { or summer }\end{array}$} & $\begin{array}{c}\text { Coccinellid } \\
\text { predators }\end{array}$ & 95.06 & ---- & ---- & 99.17 \\
\hline & True spiders & 48.03 & 15.62 & 70.19 & 35.67 \\
\hline \multirow[t]{2}{*}{ Nili } & $\begin{array}{c}\text { Coccinellid } \\
\text { predators }\end{array}$ & 96.38 & ---- & ---- & 100.00 \\
\hline & True spiders & 39.11 & 13.65 & 72.94 & 29.22 \\
\hline Mean & $\begin{array}{l}\text { Coccinellid } \\
\text { predators }\end{array}$ & 95.72 & ---- & ---- & 99.58 \\
\hline Mean & True spiders & 43.57 & 14.63 & 71.56 & 32.44 \\
\hline
\end{tabular}

On the other hand, these compounds were very toxic against the predators of coccinellid beetles and the true spiders. These results disagreement with (Omar and El-Khloy 2001) who found that,the reduction in the population size of $C$. undecimpunetata ranged between 12.7 and $14.2 \%$ when Azadirachtin (Neemazal 5\%EC) was applied against Thrips tabaci (Lind.) on onion crop.Also(El-Bessomy et al., 1997) recorded that, Biofly (compound from Beauveria bassiana ) can be used successfully to reduce the three stages of whitefly, B. tabaci, using $100 \mathrm{ml} / 100 \mathrm{~L}$ of water without causing any hazard to the tomato plants and natural enemies. Meanwhile, Abdel-Aziz et al., (2002) found that, the highest effect of Neem oil (Neemix) on the population of cereal aphids was observed 3 days after application. The residual effect extended for about 21 days post application with medium selective effect against total numbers of natural enemies after 3 days and good selective after 21 days.

\section{REFERENCES}

Abdel-Aziz, M. A.; Abdel-Alim. A. A.; Abdel-Aziz, N.A. and Morsi, G.A. (2002). Susceptibility of different wheat varieties to infestation to cereal aphids with reference to safe control approach. $2^{\text {nd }}$ Int. Conference, Plant Protec. Res.
Institute, Cairo, Egypt, 21-24 December, 2: 685-690.

Abd-Rabou, S. and Mangoud, A.A.H. (2002). Effect of natural compounds and buprofezin on the hibiscus mealybug, Maconellicoccus hirsutus and its parasitoids. $2^{\text {nd }}$ Int. Conference, Plant Protec. Res. Institute, Cairo, Egypt, 2124 December, 2: 945-947.

Balazy, S. (1993). Flora of Ploland fungi (Mycota) vol. 24. Entomophthorales. Institute of Botany, Krakow, 356pp

El-Bessomy, M.A.E.; El-Khawalka, M.H.M.; Omer, H.I.H. and El-Maghraby, H.M. (1997). Effect of the fungal insecticide (Biofly) compared with chemical insecticides in controlling different stages of whitefly Bemisia tabaci (Genn.) and its related virus. Egypt. J. Agric. Res., 75: 915-921.

El-Maghraby, M. M.; El-Zohori, M.M. and Hassanein, S.S. (1994). Relationship between insect predators and pests associated with different varieties of squash and cucumber cultivated in the newly reclaimed sandy areas of ElKhattara distrect, Egypt.Ibid., 21:969975.

Gallab, M. M.; Habashi, N. H.; Iskadar, A. K. F. and Rizk, M. A. (2011). Sensitivity of four cucumber cultivars to some piercing sap sucking pests infestation and their impact on yield. Egypt. J. Agric. Res., 89:1363-1371.

Gameel, S. M. M. (2004). Eco-Biological studies on the black melon bug, Coridius 
(Aspongopus) viduatus F. (Hemiptera: Pentatomidae) in the New Valley . Ph. D. Thesis, Fac. of Agric., Assiut Univ., 209 pp.

Gameel, S. M. M. and Sayed, A. A. (2008). Effect of cucurbit host plant species and planting dates on the population densities of the whitefly, Bemisia tabaci (Genn.) (Hom.-Aleyrodidae) at the New Valley, Egypt. Egypt. J. Agric. Res., 86: 10371043.

Gameel, S. M. M. and Sayed, A. A. (2009). Control of the greater date moth, arenipses sabella Hmpson (Pyralidae: Lepidoptera) at The New Valley-Egypt. Egyp t. J. Agric. Res., 87:1323-1328.

Gameel, S. M. M. and Sayed A. A. (2012). Comparative study on the effect of some pesticide alternatives and chemical pesticides on two piercing-sucking insect pests infesting cucumber plants at New Valley province,Egypt. Egypt Egypt. J. Agric. Res., 90: 889-896.

Henderson, C. F. and Tilton, E. W. (1955). Test with acaricides against the brown wheat mite. J. Econ. Entomol., 48: 157161

Metwally,E. M.; S. S. M. Hassanein and A. F. E. Hafsah (1995). Seasonal population activityof sucking pests infesting common bean and squash plants at Gemmeza Region, Gharbia Governorate,
Egypt. Egypt. J. Agric. Res., 73: 653667.

Omar, B. A. and El-Kholy, M. I. (2001). Comparative bio-efficacy of certain traditional insecticides against thrips infesting onion. J. Agric. Sci, Mansoura Univ., 26: 2373-2381.

Reed, D.K. and Reed, G.L. (1986). Activity of avermectin B1 against the striped cucumber beetle (Coleoptera: Chrysomelidae). J. Econ. Entomol., 79: 943-947.

Younes,M. W. F.; I.I. A. El-Sebaey; A.R.I. Hanafy and Y. N. M. Abd-Allah (2010). Survey of pests and their natural enemies on six cantaloupe Cucumis Melo L. varieties in Qaha Region, Qualyobia Governorate, Egypt., 88:739-754.

Yousri, H., El-Adawy, A. M., Ahmed, Y. M. and El-Sharkawy, T. (1995). Evaluation of some insecticides and biocide Naturalis-L (Beauveria bassiana) against whitefly Bemisia tabaci on tomatoes. $6^{\text {th }}$ Nat. Conf. of Pest and Dis. of Vegetables and Fruits in Egypt, 1: 142-146.

\section{ARABIC SUMMARY}

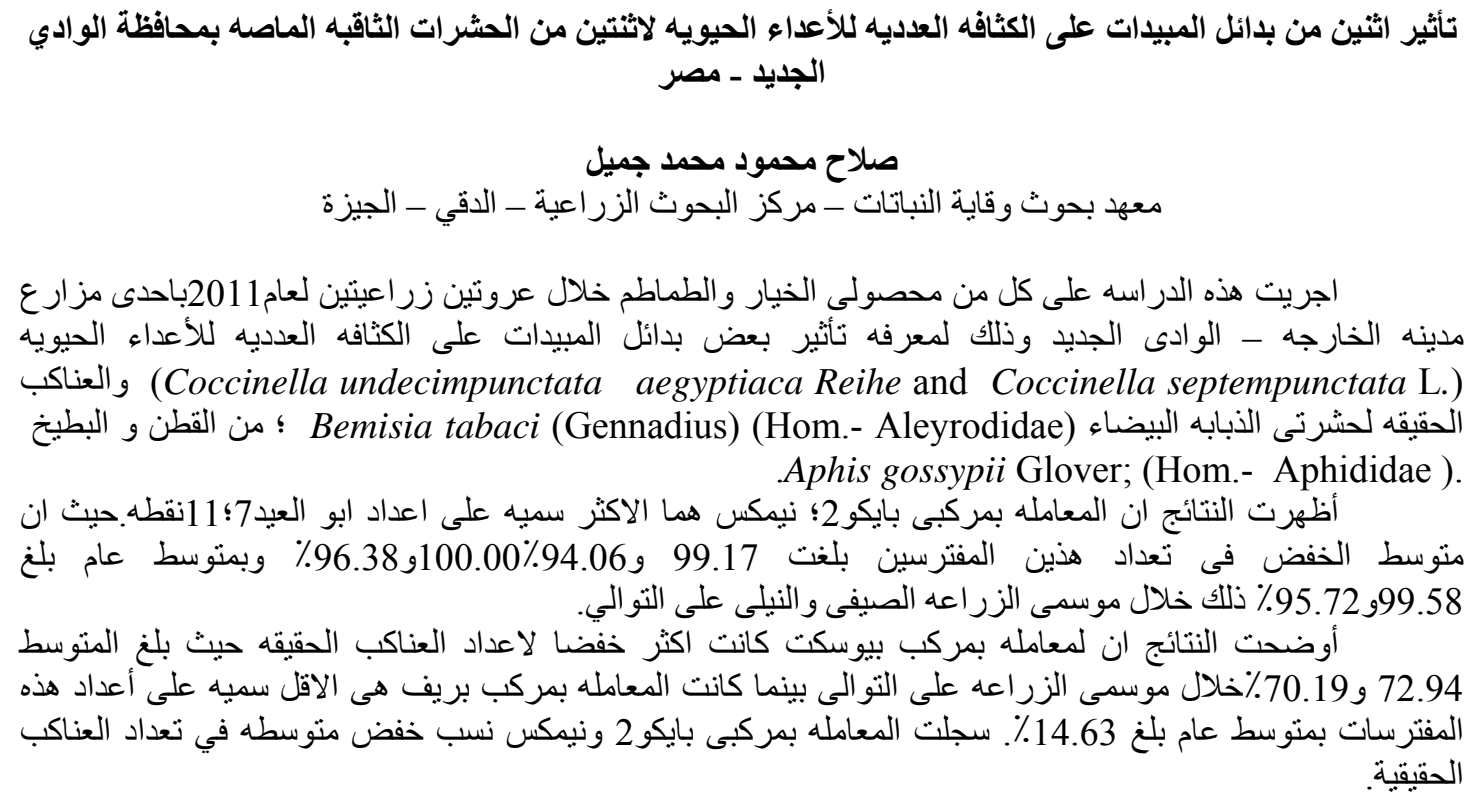

